\title{
Bridging the Gap: Student Perceptions of what the Workplace Demands
}

\author{
Ted A. Aanstoos, Steven P. Nichols \\ Department of Mechanical Engineering, The University of Texas at Austin
}

\begin{abstract}
Baccalaureate engineers have solid theoretical, analytical, and problem solving skills, but they are often ill equipped to "hit the ground running" in industry. Companies recruiting engineering graduates often urge Universities to place extra emphasis on budgeting/finance, marketing, negotiations, team building, communications, and other areas. Traditionally, these professional skills are taught on-the-job by mentoring, "stand and deliver" instruction, correspondence, computer-based instruction, etc. Such internal training may require several months of a new engineer's first year on the job.
\end{abstract}

In a recent course in Engineering Professional Responsibility, student teams were assigned a semester research project in which they were tasked to 1) Analyze their own four-year curriculum in comparison to other Universities, 2) Determine the preferred set of knowledge/skills/abilities at the entry level for the job they plan to seek, and 3) Plan the supplemental education (through seminars, short courses, certificate courses, etc) required to "bridge the gap." In researching for this project, student teams were encouraged to contact engineering alumnae, company human resource offices, and company recruiters. Key questions were asked of each of these sources with respect to a typical "dream job" defined by each team according to their preference.

This paper describes the assignment and research methods used for it, and summarizes several excellent and interesting reports that were delivered in response. It is apparent from this exercise that informing undergraduate engineering students about assets they will need in the workplace better prepares them to face, and bridge, the Gap.

\section{Background}

In 1998 ME 204, "Professional Responsibility in Engineering" was added to our curriculum as a two-credit hour, basic sequence course ${ }^{1}$. The format is a 1-hour lecture and a 1-hour workshop, both of which meet each week. The faculty instructor gives the lectures, while teaching assistants lead the workshops, which are limited to 30 students each. Stated objectives of the course included:

- Develop an understanding of the Professional Responsibility of Engineers

- Develop analytical skills for identifying and evaluating issues of Professional Responsibility

\footnotetext{
"Proceedings of the 2001 American Society for Engineering Education Annual Conference \& Exposition, Copyright 2001, American Society for Engineering Education”
} 
- Develop an understanding of the differences between moral and professional responsibility

- Develop an appreciation of ancillary workplace tasks (health and safety, regulatory and code compliance, and hazardous material responsibility) as crucial engineering functions and duties.

The course is organized by topic. Topics are introduced in Lecture, and specific Workshop activities are prepared that illustrate the topic under consideration. Major topics covered include:

- Intellectual Property

- Engineering Codes of Ethics

- Regulatory Compliance and Environmental Law

- Engineering History and the evolution of Professional Societies

- Academic and Professional Honesty

- Design Codes and Standards

- Workplace and Product Safety

- Engineers and Society

- Global Ethics in the New Millennium

- Continuing Education

There is no textbook; instead a compiled and edited course pack $^{2}$ is used. The readings collected here were chosen to supplement the topics, and include selections from work by prominent authors, (many of them engineers) on the history of technology and engineering, design and creativity, the anatomy of failure, ethics and engineering, engineering and public policy, and intellectual property and the law. Course objectives, readings, lecture topics and workshop activities address six of the eleven ABET 2000 criteria; $^{3}$

- An ability to function on multi-disciplinary teams

- An understanding of professional and ethical responsibility

- An ability to communicate effectively

- The broad education necessary to understand the impact of engineering solutions in a global/societal context

- A recognition of the need for and an ability to engage in life-long learning

- A knowledge of contemporary issues

Graded course work includes several short writing assignments, a case study report, and a semester research project. The case study, report, and the semester research project are done by student teams (the same team was used in a given semester for all team assignments), and each of these was presented both in writing and orally, with equal grade weight placed on each method of presentation. All students on a Team received the same grade. Team size ranged from 3-8 students depending on roster size.

The Case Study Reports addressed historical cases in engineering mishaps and/or successes that were selected to best exemplify a variety of lessons in professionalism, communication, safety, ethics, and public policy. Cases were selected that were well documented, of high interest to 
students, and not so complicated that first- and second-year engineering students could not grasp the technical aspects. ${ }^{4}$

The semester research report is assigned in lieu of a written final exam. All students report on the same topic each semester, and students collaborate in the same teams used for the case study reports. Research topics vary by semester; these projects are described below.

Student Code of Ethics. Student teams prepare and propose a Code of Ethics for undergraduate students at the College of Engineering of The University of Texas at Austin. UT Austin applies a standard disciplinary policy defining unacceptable conduct (including academic dishonesty) to all students, but there is not at present a separate student code of ethics within the College of Engineering. Students were required to include major sections on 1) Background (the use of honor codes, etc at other major US universities), 2) Elements of the proposed Code (tenets and principles modeled on ASME/NSPE codes, 3) Means of oversight and enforcement, etc) and 4) Implementation Plan (getting consensus among students, faculty and administration, and managing the transition period). A similar Code has since been made a goal in the Strategic Plan of the Mechanical Engineering Department. Interestingly, at least one Team proposed that no Code should be introduced, but rather the status quo should be upheld-and offered wellreasoned arguments to support their position. Also it is good to note here that the best research project on this topic earned a panel presentation by two Team members at the 2000 ASME International Congress and Exposition. ${ }^{5}$

Bridging the Gap. Ample anecdotal evidence suggests that while BSME graduates may have solid theoretical, analytical, and problem solving skills, they are often ill equipped to "hit the ground running" in industry. Campus recruiters and visiting committees often urge that we give our students extra emphasis on budgeting/finance, marketing, negotiations, team building, and written/oral communications, and other areas. Currently, companies must teach their newhires these professional skills by on-the-job mentoring, contracted "stand and deliver" instructors, self-paced correspondence, computer-based instruction, or a mix of these -- often a new engineer is mired in some sort of internal training for several months of his/her first year on the job. In this research project, students are asked to analyze their own four-year curriculum, determine the preferred set of assets at the entry level to the job they plan to seek upon graduation, and plan the supplemental education (through seminars, short courses, certificate courses, etc) required to bridge the gap. The remaining sections of this paper describe this assignment and its results in more detail.

Team-Proposed Research Project. In some semesters, Teams were told to select their own research topic using whatever criteria they wished, as long as the topic reflected a significant portion of the topics, goals, and objectives of the course. In these assignments the key elements of the project were to lay out the Background, identify the Stakeholders, show the Relevance to Engineering Professionalism, estimate their own Career Impact arising from this topic, and present Conclusions and Recommendations. Not surprisingly this assignment yielded many interesting and well-researched reports.

\section{Bridging the Gap}

\footnotetext{
"Proceedings of the 2001 American Society for Engineering Education Annual Conference \& Exposition, Copyright 2001, American Society for Engineering Education”
} 
Methods and Approaches. In arriving at a perception of their expected level of preparedness for the workplace, students began by analyzing their own four-year curriculum for the BSME degree at UT Austin, and comparing it to similar programs at one or more comparable engineering universities. Part of this analysis was also to contact and interview engineer alumnae from UT Austin to get their perspectives from the other side of graduation. Then they were asked to formulate a job description of their hypothetical "dream job"-i. e., what engineering position would they prefer to achieve, and in which industry. With the objective to best prepare themselves for their targeted employment, Teams then were asked to contact representative human resources specialists, hiring managers, and recruiters (and in many cases friends and relatives) in the industries/business of interest, in order to recognize the knowledge, skills, and abilities needed in their dream job. Finally, Teams proposed modifications and/or additions to their 4-year curriculum that if adopted would presumably help them to "bridge the gap" between graduation and professional employment.

Curricula Comparison. Under the 2000-2002 catalog, a BSME degree from UT Austin requires a minimum of 128 semester hours of coursework, which includes Basic Sequence courses, Major Sequence courses, and Other Required courses (technical and non-technical electives, natural sciences/math elective, interdisciplinary engineering courses, and state-mandated history and government courses). ${ }^{6}$ Teams studied this curriculum and compared it to the corresponding requirements at other engineering colleges and universities (Table 1).

Table 1. Colleges and Universities studied for comparison to UT Austin
\begin{tabular}{|l|c|}
\hline Institution & Chosen by $($ N) Teams \\
\hline Georgia Institute of Technology & 4 \\
\hline Louisiana State University & 1 \\
\hline Massachusetts Institute of Technology & 3 \\
\hline Oklahoma University & 1 \\
\hline Purdue University & 5 \\
\hline Rice University & 2 \\
\hline Stanford University & 1 \\
\hline Texas A\&M University & 6 \\
\hline Texas Tech University & 1 \\
\hline Tulane University & 1 \\
\hline University of California-Berkeley & 5 \\
\hline University of California-San Diego & 1 \\
\hline University of Colorado-Boulder & 1 \\
\hline University of Florida & 1 \\
\hline University of Houston & 1 \\
\hline University of Illinois-Urbana/Champaign & 2 \\
\hline University of Michigan-Ann Arbor & 2 \\
\hline University of Washington & 2 \\
\hline University of Wisconsin-Madison & 2 \\
\hline
\end{tabular}

Schools were chosen for comparison on basis of reputation, similar national rankings (especially U. S. News and World Report), or in some cases because of family/friend connections. Not surprisingly, these schools all compared very well on the basis of required course content. This result is expected because of the constraints imposed by the 4-year

"Proceedings of the 2001 American Society for Engineering Education Annual Conference \& Exposition, Copyright 2001, American Society for Engineering Education” 
bachelors degree format, the efforts by all accredited engineering schools to meet ABET criteria, and no doubt by the fact that all major colleges and universities are responding to the dynamic needs of the hiring marketplace.

Dream Jobs. Teams were asked to define a hypothetical job function and industry sector in which they would like to be employed-a "dream job" for purposes of determining those qualifications and qualities that would presumably make them more competitive in the recruiting arena upon graduating. Team members used their academic areas of interest, their work experience, advice of friends or relatives, and no doubt several other factors to come up with a list of mechanical engineering activities that is reflective of today's high technology, international, energy-dependent world economy, as shown in Table 2.

Table 2. Team-defined dream jobs

\begin{tabular}{|l|l|}
\hline Engineering Job Category & Field or Industry \\
\hline Design engineer (selected 2 times) & Aerospace \\
\hline Design engineer (selected 2 times) & Automotive \\
\hline Design engineer & Biotechnology \\
\hline Design engineer & HVAC \\
\hline Design engineer & Semiconductor tools \\
\hline Engineering sales & Software \\
\hline Manufacturing engineer & Automotive \\
\hline Manufacturing engineer & Computer \\
\hline Manufacturing engineer & Unspecified \\
\hline Operations engineer & Petrochemical \\
\hline Power distribution engineer & Utilities \\
\hline Power plant engineer & Utilities \\
\hline Production specialist & Petrochemical \\
\hline Project engineer & Petrochemical \\
\hline Research and development engineer & Computer \\
\hline Research engineer & Unspecified \\
\hline
\end{tabular}

Alumni Survey. With the assistance of the College of Engineering, an email list was made available to Teams for surveying mechanical engineering alumnae from UT Austin. 170 addresses were generated from the database ${ }^{7}$, based on positive responses by addressees on the question of their being willing to assist undergraduate students through personal contact. This list was parsed into equal sub lists and randomly distributed to the Teams, with each Team receiving approximately 9-10 alumni contacts. Unfortunately, in spite of College efforts to maintain an up-to-date alumni database, some $30 \%$ or more of the email addresses used were not deliverable, however the response rate for those addresses that were good was quite high.

The questionnaires sent by the Teams were not uniform, and did not reflect a serious attempt to conduct a formal statistical survey. Other universities have conducted high-level research on the situation and opinions of their engineering alumnae according to formal metrics, such as New Mexico State University.

Alumni questions were geared to gather information on how many years the respondent had been on the job, what on-the-job training was expected and/or required after initial hire, and

\footnotetext{
"Proceedings of the 2001 American Society for Engineering Education Annual Conference \& Exposition, Copyright 2001, American Society for Engineering Education”
} 
what educational assets at the undergraduate level were most helpful on the job (and conversely, what assets would have been helpful if available). Most survey respondents had been employed as engineers less than 10 years, and most replied that they required anywhere from two to six months initial training before they were fully productive. Alumni felt that this curve could have been shortened if the undergraduate curricula had been better tailored to their job requirements, but most seemed to accept some level of corporate training as part of the entry cost to the profession. On the question of continuing education, a large fraction of alumni report that their companies fund a significant portion of their ongoing learning, ranging from a fixed budget per year (usually \$5000) to a portion (up to $75 \%$ ) of tuition and fees for advanced degree costs. These are major benefits and alumni clearly utilize them to great benefit (for instance, numerous respondents reported having achieved their MBA degrees with corporate assistance).

Responding alumni were vocal about the availability and applicability of academic courses and other resources of their undergraduate curricula. Table 3 summarizes their responses on such questions. It should be noted that only a few alumni took the position that such basic courses as Physics and Calculus were not job-critical; a somewhat larger number did not value the mandatory history and government. Outnumbering these were a significant number of respondents who wished that there were more time at the baccalaureate level for foreign language study, cross-discipline electives, or fine art subjects.

Table 3. Summary of alumni comments on educational resources at undergraduate level

\begin{tabular}{|c|c|c|c|}
\hline & "Hard" Topics & "Soft" Topics & Intangibles \\
\hline $\begin{array}{l}\text { Courses/assets } \\
\text { available; not } \\
\text { job-critical }\end{array}$ & $\begin{array}{l}\text { - Physics } \\
\text { - Numerical analysis } \\
\text { - Calculus/differential } \\
\text { equations }\end{array}$ & $\begin{array}{l}\text { - Mandatory history } \\
\text { and government } \\
\text { - Non-technical } \\
\text { electives }\end{array}$ & \\
\hline $\begin{array}{l}\text { Courses/assets } \\
\text { available; job- } \\
\text { critical }\end{array}$ & $\begin{array}{l}\text { - Thermodynamics } \\
\text { - Material sciences } \\
\text { - Statics/dynamics }\end{array}$ & - Internships & \\
\hline $\begin{array}{l}\text { Courses/assets } \\
\text { not available; } \\
\text { job-critical }\end{array}$ & $\begin{array}{l}\text { - Computer } \\
\text { programming } \\
\text { - Software } \\
\text { applications } \\
\text { - Numerical analysis } \\
\text { - Ceramics/Composite } \\
\text { s } \\
\text { - Solid modeling } \\
\text { - Manufacturing } \\
\text { processes }\end{array}$ & $\begin{array}{l}\text { - Technical writing } \\
\text { - Oral communications } \\
\text { - Team skills } \\
\text { - Labor relations } \\
\text { - Quality engineering } \\
\text { - Negotiation skills } \\
\text { - Budgeting/cost } \\
\text { controls } \\
\text { - Finance/marketing } \\
\text { - Diversity/sensitivity } \\
\text { - Ethics } \\
\text { - Safety } \\
\text { - Management } \\
\text { - Regulatory } \\
\text { requirements }\end{array}$ & $\begin{array}{l}\text { - Interpersonal } \\
\text { relationships } \\
\text { - Work experience } \\
\text { - Problem solving } \\
\text { - Work ethic } \\
\text { - Time management } \\
\text { - Multi-disciplinary } \\
\text { studies } \\
\text { - Sports/extracurricula } \\
\text { r activities }\end{array}$ \\
\hline
\end{tabular}

"Proceedings of the 2001 American Society for Engineering Education Annual Conference \& Exposition, Copyright 2001, American Society for Engineering Education” 
Industry response. Through the cooperation of the Engineering Career Assistance Center, College of Engineering, UT Austin, Team members were placed in touch with hiring professionals at companies typical of their composed engineering jobs. Students were then free to ask these hiring managers and human resource specialists questions regarding recruiting goals, academic and personal qualities sought in job candidates, company policies on contributing to continuing engineering education, and other matters. Again, this was informal questioning, not hard survey tactics, so information received was qualitative rather than quantitative. Also, the names of specific companies contacted are not listed here in order to safeguard information discussed with students that might be privileged.

Teams contacted companies representing all the industry sectors listed in Table 2. As with the alumni survey, standard questionnaires were not used, so company responses are summarized in Table 4.

Table 4. What companies are looking for in recruiting new Mechanical Engineering graduates.

\begin{tabular}{|c|c|c|}
\hline "Hard" Topics & "Soft" Topics & Intangibles \\
\hline $\begin{array}{l}\text { - Hardware management } \\
\text { - Information management } \\
\text { - Cost analysis } \\
\text { - Advanced finite element } \\
\text { analysis } \\
\text { - Solid modeling } \\
\text { - Software } \\
\text { development/programming } \\
\text { - Manufacturing processes }\end{array}$ & $\begin{array}{l}\text { - Communications } \\
\text { - Written } \\
\text { - Oral } \\
\text { - Technical and } \\
\text { Persuasive } \\
\text { - Teamwork skills } \\
\text { - Product planning } \\
\text { - Finance/marketing } \\
\text { - Accounting } \\
\text { - Ethics }\end{array}$ & $\begin{array}{l}\text { - Interpersonal relations } \\
\text { - Sensitivity/diversity } \\
\text { - Work ethic } \\
\text { - Leadership } \\
\text { - Work experience } \\
\text { - Problem } \\
\text { identification/solving } \\
\text { - Foreign language }\end{array}$ \\
\hline
\end{tabular}

Student plans to bridge the gap. Armed with all the above data and more, student Teams were now tasked to bridge their own perceived gap between graduation and Day One as an engineer. Most of these plans involved extension of the academic curricula to include as many of the identified Industry requirements (Table 4) as possible. Strategies to do this included:

- Add one to three standard courses (up to a full added year)

○ Note: this approach is consistent with the move to establish a standardized 5Year Master of Engineering degree plan ${ }^{9}$

- Build new certificate program similar to several already in place

- At UT Austin, these include the Business Foundation Program and Elements of Computing (each offered in the 2000-2002 catalog; see Note 6)

- Use of seminars, short courses, web-based learning (team-taught and paid by employer)

- Elimination of mandated history/government course content

- Establish mentoring relationships early on with prospective employers (perhaps with early employment contracts)

- Increase the availability of internships (perhaps require internships)

\footnotetext{
"Proceedings of the 2001 American Society for Engineering Education Annual Conference \& Exposition, Copyright 2001, American Society for Engineering Education”
} 
It would not be realistic to implement some of these Team tactics. For instance, Statemandated course content is a legislative requirement and cannot be waived at the Institution level, and total coursework hours are regulated. However many of the Team suggestions are consistent with gap-bridging efforts at UT Austin and other major engineering schools and represent a reasonable compilation of observations encompassing student as well as professional input.

\section{Conclusions}

Engineering institutions compete at each end: we attempt to recruit high-quality undergraduate students for an intelligent, energetic, diverse population in and out of the classroom, and four (or five) years later we market well-documented, high-potential, newly-minted engineering graduates to the world corporations, large and small, that fuel the global economy. We will compete more effectively at each end of this cycle if we understand and prepare for the gap between campus and the workplace. We can do this by working closely with our students, our alumnae, and their employers.

These exercises indicate that undergraduate engineering students are capable of executing a reasonable analysis of engineering curriculum (with the input from professionals with engineering experience that relates to the curriculum) early in their academic career. More importantly, however, faculty have found that these exercises encourage engineering students to develop an understanding of their required curriculum and to develop an expectation (or vision) for their continuing educational needs not only for their undergraduate career, but also for their professional life. This vision of their needs better empowers engineering students to address the "gap" between their current skills (at graduation) and those needed in the workforce (immediately after graduation). The gap that graduates experience at the transition from education to the profession is only the first of many they will face as they experience a lifetime of professional transition.

\section{Acknowledgments}

The authors wish to recognize and thank the following individuals for their assistance to students conducting the research presented in this paper:

Sandra L. Jacobson, CFRE

Director, Friends of Alec

Ann Page, Program Coordinator

Engineering Career Assistance Center

College of Engineering

The University of Texas at Austin

\footnotetext{
"Proceedings of the 2001 American Society for Engineering Education Annual Conference \& Exposition, Copyright 2001, American Society for Engineering Education”
} 


\section{TED A. AANSTOOS}

Ted Aanstoos is a Senior Lecturer in the Department of Mechanical Engineering, The University of Texas at Austin, where he teaches undergraduate courses in Professional Responsibility in Engineering and Engineering Graphics. He assists in course development, is a mentor to undergraduate and secondary students, and serves on the planning committee of the Center for Teaching Effectiveness. He is also a Research Engineer at the Center for Electromechanics. Mr. Aanstoos is a Member of ASME and a Registered Professional Engineer in Texas.

\section{STEVEN P. NICHOLS}

Steve Nichols is Associate Chairman and Director of the Senior Design Project Program in the Department of Mechanical Engineering, The University of Texas at Austin. Dr. Nichols serves on the Board of Directors of the National Institute for Engineering Ethics and the Association for Manufacturing Excellence.

\section{Bibliography}

${ }^{1}$ Moore, C., Aanstoos, T. and Nichols, S. "Designing Assignments for an Engineering Course in Professional Responsibility-The Challenges and Rewards of Encouraging Analysis," ASEE Gulf Southwest Section Meeting, New Mexico State University, Las Cruces, New Mexico-April 7, 2000

${ }^{2}$ Aanstoos, T. (ed.) "Readings in Engineering Ethics and Professionalism," January, 2000.

${ }^{3}$ Engineering Accreditation Commission, Accreditation Board for Engineering and Technology, Inc. "Criteria for Accrediting Engineering Programs: Effective for Evaluations during the 2000-2001 Accreditation Cycle," Baltimore, MD. November 1999.

${ }^{4}$ Five cases were studied each semester-the Hyatt-Regency walkway collapse, the Ford Pinto gas tank controversy, the Challenger explosion, the Citicorp Center construction problem, and the Bay Area Rapid Transit history.

${ }^{5}$ Chang, Angela and Campbell, Jeffery. "Toward a Student Code of Ethics", Panel Presentation, Session E\&TM-15, Industrial Ethics and the Engineering Profession, ASME IMECE 2000, Orland FL, November 8, 2000.

${ }^{6}$ The Undergraduate Catalog 2000-2002, The University of Texas at Austin, Chapter 6, College of Engineering. http://www.utexas.edu/student/registrar/catalogs/ug00-02/ch06/ch06j.html bsme

${ }^{7}$ The email list is owned and maintained by the Friends of Alec, College of Engineering, The University of Texas at Austin. Used by permission.

${ }^{8}$ L.A. Riley, L. A. et al. "Assessing our engineering alumni: determinants of success in the workplace," ASEE Gulf-Southwest 2000 Conference, Las Cruces, NM, April 2000.

${ }^{9}$ P. Dorato, C.Q. Ford, J. Jordan, W. Lyons. "The Master of Engineering: The Professional Degree of the Future," ASEE Gulf-Southwest 2000 Conference, Las Cruces, NM, April 2000. 